\title{
Determinants of Value Chain Analysis of Solar Photovoltaic Industry in Kathmandu Valley
}

\author{
Anita Rizal ${ }^{l}$
}

\begin{abstract}
The objective of this paper is to find out key factors influencing target market of solar photovoltaic industry; and identify ways on how to reduce cost of sales in solar photovoltaic industry in Nepal. It also analyzes better ways of marketing solar photovoltaic system in current market. The conceptual model taken for this study comprises of Porter's (1985) value chain analysis theory which has identified two sequences of activities i.e. primary and support activities. Exploratory research has been used where primary data is collected through structured questionnaire distributed among 120 individual sellers of solar photovoltaic system inside Kathmandu valley. The data collected are analyzed using SPSS 16.0 which is coded and tabulated by Microsoft Excel spreadsheet application.

The result of the analysis of the data shows that factors influencing value chain of solar PV industry are infrastructure (mostly furniture, workshop, showroom, capital and human resources in less number) needed to set up a company, imported from different countries, distribution channel, subsidy claim, marketing medium and after sales service. Few companies import huge quantity of solar related products. Most of the companies targeting direct customer don't claim subsidy directly rather they claim via other pre-qualified companies. Also these companies consider radio advertisement to reach customers at large rather than any other medium of marketing. These companies value warranty and repair \& maintenance services as an after sales service. Although few of the solar photovoltaic systems are manufactured in Nepal, they prefer to import these items rather than promote Nepal made products. Thus, these factors have created value from import to service to the customers.
\end{abstract}

Key words: value chain; solar photovoltaic; porter; alternative energy promotion centre and primary survey

\section{Introduction}

There has been a global increase in the usage of renewable energy over the past decades. The Global Status Report on Renewable Energy in 2012 has indicated that renewable energy accounted for approximately $16.7 \%$ of global energy consumption in 2010. Renewable energy sources, including hydropower, now

\footnotetext{
Ms. Rizal is an MBA Graduate from Ace Institute of Management, affiliated to the Pokhara University.

Corresponding Email: anita.rijal18@gmail.com
} 
154 Rizal: Determinants of Value Chain Analysis of Solar Photovoltaic Industry in Kathmandu Valley

account for $16.28 \%$ of total installed U.S. operating generating capacity: water $8.57 \%$, wind $-5.26 \%$, biomass $-1.37 \%$, solar $-0.75 \%$, and geothermal steam $0.33 \%$ which is more than nuclear $(9.24 \%)$ and oil $(4.03 \%)$ combined. China, Japan and the United States again account for the majority of capacity added, but emerging markets on all continents contribute significantly to global growth, driven largely by the increasing cost-competitiveness of solar Photovoltaic (PV) (Renewable 21, 2016).

Since geography of Nepal doesn't support wind and geo thermal energy, the electricity production is limited to hydropower. Nepal being the second richest country in water resources, it is still facing load shedding of 7 hours a day during 2016 as stated by Nepal Electricity Authority. In order to have power supply during load shedding hours, the best option recognized by the government is solar PV system. According to Hydroelectricity Investment \& Development Company Limited, current estimates are that Nepal has approximately 40,000 MW of economically feasible hydropower potential. However, the present situation is that Nepal has developed only approximately $680 \mathrm{MW}$ of hydropower.

The electricity demand in Nepal is increasing by about 7-9\% per year. There is not enough power supply to meet the current demand. In present context, there are more than 140 sellers of solar photovoltaic system all around Nepal (Solar Electric Manufacturers' Association Nepal, SEMAN, 2016) and more sellers are encouraged to start solar business from local level as this business seems to be promising and in more demand than any other alternative energy businesses. These sellers all work under the supervision of Alternative Energy Promotion Center (AEPC). Most of the largest companies purchase this product related to solar home system from other countries and then distribute among the local sellers. Accordingly, the local sellers are liable to provide after sales service and warranties as they face customers directly. There are around 6,00,000 PV systems installed in the country by the end of 2015 covering 75 districts (AEPC, 2015). People still do not prefer using solar PV as an alternative during loadshedding because the system cost more in the first year but it is inexpensive alternative in long run.

Since the usage of solar PV has not increased in satisfactory level, AEPC has implicated subsidy in both areas. The effort here is to find better ways of reaching customers and reducing the cost of sales. Solar PV being the most important alternative energy, value addition and servicing is the prime thing. Study of solar PV system, so far, has not been addressed explicitly. At most cases, the top priority has been given to subsidy and certification. Xiang et al. (2013) state that certification has impact on buyer however, not all quality assurance programs are successful in every sector (Roberts, 2011). On the other side, factors like organization's infrastructure, capital investment, human resources, after sales 
service, promotion are still lacking behind in the solar businesses. However, these are crucial factors in determining the value chain process (Porter, 1985). It is expected that this approach does much to help managers understand where value is created in the value chain.

The objectives of the study is to find out key factors influencing target market of solar PV industry, to analyze better ways of marketing solar PV system in current market and to determine ways to reduce cost of sales in solar PV industry.

In order to fulfill the objectives of the study the research question that are addressed as: what are the ways of reducing cost of sales? Is there any effective distribution channel to reach customer? What are the effective ways of marketing solar PV system?

This study offers an insight into finding ways to reduce cost of sales so that solar PV home system is easily accessible to customers. The researcher has used qualitative approach to know how the products are being purchased, how a system is made available to customers in more cost effective way.

Thus this study provides a better insight which will be helpful for AEPC in coming up with new programs to reach more customers. It will also be easier for AEPC to tie up with private institution to increase the usage of solar PV.

\section{Review of Literatures}

Mowen and Hansen (2011) describe the value chain as "set of activities required to design, develop, produce, market deliver and provide post-sales service for the product and services sold to the customer." In addition, this involves the product interrelations inbound logistic and operations and then market interrelations outbound logistic, marketing, sales and after sales service (Ireland \& et al. 2009, Mowen and Hansen 2011).

The study conducted by Achchuthan \& Kajananthan (2012) has focused on key value chain actors in the dairy sector; to find key factors influencing value chain analysis for dairy sector; to discover the strengths and weakness of each value chain actors; to discover the opportunities and threats of each value chain actors; to suggest the value chain actors to strengthening the dairy sector in accordance with benefits of socio and economic point of view. Meanwhile, problems such as irregularity in the development of the industry, lag of after-sales services, lack of human resources and inadequate government support for small and medium-sized enterprises also restrict further development of the industry (Institute for Labor Studies, 2009).

Xiao (2010) shows that certification has little impact on demand for childcare services if alternative quality information is already provided by firms. The studies has observed the positive relationship between the human resource development 
and organizational performance according to the large and expand body of literature in which human resource management is taken as an independent and intangible variable.

The study made by Malik et al. (2016) has the objective to analyze the value chain of PV in Pakistan and to describe the existing and required supply structure and customer segmentation. Winter et. al (2003) has conducted a study to assess the development and performance of value chain firms in the Korean furniture industry, to know the factors that determine profitability in network firms and to identify appropriate partners for a hub firm. The study was based on quantitative study i.e. questionnaire was designed and sent to 127 individual sellers of furniture. The study shows that when the firms possess resources, they are more likely to participate in a network. Firms are more likely to divest themselves of inefficient activities within their value chain, such as purchasing, marketing and production, when they participate in networks.

Olson (2014) has suggested the Green Innovation Value Chain (GIVC) framework to analyze the photovoltaic solar power chain, where financial deficits are found in each link that are needed to be reduced or eliminated through technology advancements, subsidies, or changes in market conditions in order to provide the conditions necessary for the technology to achieve mass-market acceptance and positive financial returns.

The key barrier to cost reductions in the solar water heating industry is found to be the small size of the industry which leads to an inability to source material, especially copper, at competitive prices. (Du Toit, 2010). Hergert and Morris (1989) state that "the fundamental notion in the value chain analysis is that a product gains value as it passes through the vertical stream of production within the firm. When created value exceeds costs a profit is generated".

Although there are various studies conducted around the world in different areas of value added services in solar industry, the literature above shows that there are not many studies conducted on value chain analysis of solar PV system in Nepal. Thus, this study provides a new direction to the research as the topic is completely new in the context of Nepal. To overcome this limitation, this research has been about the distribution channel, marketing approach to reach the target, after sales service, warranties, human resources required to have an effective organization. It identifies better ways of reducing cost of sales and reaching customers with effective product model. Besides, various ways of solving subsidy programs are also identified to make this sector more understandable. It provides an insight into the solar PV industry and the perception of the solar companies regarding different factors of value chain analysis. 


\section{The Methodology}

\subsection{Conceptual framework}

Porter (1985) propounded value chain theory in his book "Competitive Advantage". This theory has identified two sequences of activities i.e. primary and support activities. Primary activities include inbound logistics, operations, outbound logistics, marketing \& sales and service. Support activities include firm infrastructure, human resource management, technology and procurement. The idea of the value chain is based on the process view of organizations which is made up of subsystems each with inputs, transformation processes and output. The firm's margin or profit then depends on its effectiveness in performing these activities efficiently, so that the amount that the customer is willing to pay for the products exceeds the cost of the activities in the value chain. It is in these activities that a firm has the opportunity to generate superior value. A competitive advantage may be achieved by reconfiguring the value chain to provide lower cost or better differentiation. Cost advantage is achieved by better understanding costs and squeezing them out of the value adding activities whereas differentiation is attained by focusing on those activities associated with core competencies and capabilities in order to perform better than their competitors.

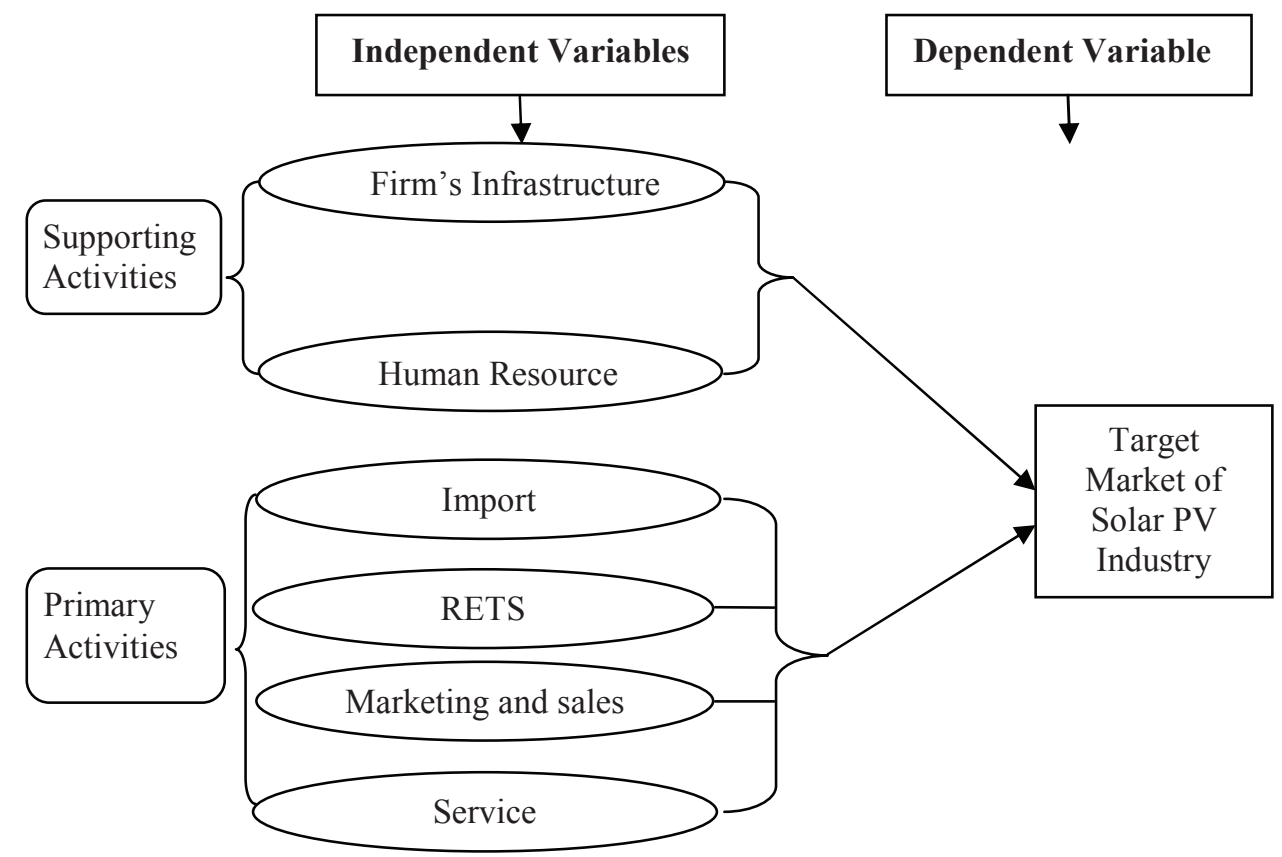

Figure 1. Conceptual framework 
The major independent variables applied here are firm's infrastructure consists of furniture, workshop, showroom, capital and human resource; human resource consists of recruiting, hiring, training, developing, compensating and dismissing or laying personnel; import includes purchase of solar panel, battery, charge controller, bulbs, inverters, etc from different parts of the world. Although the biggest exporter of solar related product in the world is Taiwan and USA but our Nepalese market is dependent on Asian market such as China, India, Bangladesh and Japan.; RETS is an autonomous body governed by "renewable energy test station rules 2007" framed under clause 31 of Nepal Academy of Science and Technology (NAST) Act 1991. Today, it has a well-equipped laboratory with sophisticated equipment and instrument for testing and measuring the quality of Solar PV components supported by trained and qualified technical personnel. Marketing includes activities such as informing buyers about products and service, and facilitate purchase such as use of radio, T.V, newspaper, product demonstration and exhibition; service includes all the activities required to keep the product working effectively for the buyer after it is sold and delivered for example, after sales service, warranty, installation, repair \& maintenance, home delivery and exchange offer. The dependent variable in the study is the target market of solar PV industry such as wholesaler/ dealer, retailer and direct customer.

\subsection{The data}

The sample size selected for the study was 120 individual sellers of solar PV system inside Kathmandu Valley from SEMAN's membership list. It has been selected by the method of non-random convenient sampling. The total population of the study is the sellers of solar PV system within Kathmandu Valley who offer solar panel, battery, charge controller, wire, switches, bulbs and support structures or the whole system. As part of primary data collection, the data are collected from the respondents through distribution of structured questionnaire. Whereas, secondary data includes various reports, articles and policies formed by AEPC and SEMAN and relevant books, journals and articles, literatures, reports, meetings, websites and unpublished masters' degree thesis. The study has used structure questionnaire comprising of questions such as single response, multiple choice, quantitative, rating and likert scale and open ended questions. Self-administered and researcher administered techniques have been used as per the requirement while collecting data through the structured questionnaire. Steps have been taken to ensure the validity and reliability of the research. For the validity of data, questionnaire has been developed after referring to the literature reviews as well as market scenario in Nepal. Timely visit with the expert instructor has also helped in developing higher standard questionnaire. For the reliability of data, cross check 
questions has been included in the questionnaire. Pre-testing of the questionnaire has been carried out prior to the questionnaire distribution.

\subsection{Data analysis methods}

Data management and analysis are done descriptively as well as inferentially. Under the descriptive analysis, percentage/frequency distribution, cross tabulation, mean, median etc are used. Similarly, in case of inferential analysis, both parametric and non-parametric tests are used to determine and study various characteristics of the sample. Parametric tests such as one way ANOVA, independent sample t-test, and Pearson's correlation and non-parametric tests such as chi-square test are used in the study. The findings from SPSS 16.0 have been copied from Ms-excel to Ms-word. The data and findings have been presented in the form of tables and charts and also interpreted in an accurate and clear manner.

The null hypotheses are as follows, Hoi: There is no significant relationship between factors of value chain (firm infrastructure, Human Resource, import, RETS, AEPC, marketing, service) and target market of solar PV industry, marketing tools and target market and ways of reducing cost of sales and target market, where $i=1,2$ and 3 .

\section{Results and Discussions}

\subsection{General profile of the respondents}

The brief description of the respondents in this survey has been shown below. The respondents are categorized on the basis of the target market they have served.

\begin{tabular}{|l|l|}
\hline Target Market & No. of respondents \\
\hline Wholesaler/ Dealer & 24 \\
\hline Retailer & 33 \\
\hline Direct Customer & 63 \\
\hline Total & 120 \\
\hline
\end{tabular}

This study has taken companies targeting different market segment that is 24 companies targeting wholesaler and dealer, 33 companies targeting retailer and 63 companies targeting direct customer. Out of total companies, $8.3 \%$ of the companies are established between (3-5) years, $32.5 \%, 15.8 \%, 8.3 \%$ and $5 \%$ of the respondent's company is established 6-10 years, 11-15 years, $1-2$ years and 15 years ago respectively. Thus, most companies are established between 3 to 5 years. Among the total respondents, more than half companies have employed 4-15 employees whereas only $1 \%$ company provide employment opportunity to more than 46 employees. 


\subsection{Descriptive statistics}

Out of the 120 respondents, $91.70 \%$ of the companies who have targeted wholesaler/dealer consider furniture as an important infrastructure to set up a company. $79.20 \%$ of the companies who have targeted wholesaler/dealer consider workshop as an important infrastructure to set up a company. $87.5 \%$ of the companies who have targeted wholesaler/dealer consider showroom as an important infrastructure to set up a company. $100 \%$ of the companies who have targeted wholesaler/dealer consider capital as an important infrastructure to set up a company. $66.70 \%$ of the companies who have targeted direct customer consider HR as an important part to set up a company. Except for direct customer serving companies, most of the companies do not consider HR as an important part to set up a company.

\subsection{Analysis of variance}

Under the inferential analysis, hypotheses are tested using mean of all the factors of value chain analysis. The research hypotheses determined in this study has been tested using respondents categorized as target markets they have focused on such as wholesaler/dealer, retailer and direct customer.

Table 1. Analysis between factors of value chain of solar PV industry and target market

\begin{tabular}{|c|c|c|c|c|c|c|}
\hline $\begin{array}{c}\text { Factors of value chain of } \\
\text { solar PV }\end{array}$ & $\begin{array}{c}\text { Target } \\
\text { Market }\end{array}$ & Mean & $\begin{array}{c}\text { Std. } \\
\text { Deviation }\end{array}$ & \begin{tabular}{|c|} 
F- \\
value
\end{tabular} & \begin{tabular}{|c|}
$\mathbf{P}-$ \\
value
\end{tabular} & Remarks \\
\hline \multirow{4}{*}{$\begin{array}{l}\text { Firm's infrastructure } \\
\text { increases the brand } \\
\text { value of the company }\end{array}$} & $\begin{array}{l}\text { Wholesaler/ } \\
\text { Dealer }\end{array}$ & 3.75 & 0.897 & \multirow{4}{*}{0.974} & \multirow{4}{*}{0.381} & \multirow{4}{*}{$\begin{array}{l}\text { Not } \\
\text { significant }\end{array}$} \\
\hline & Retailer & 3.82 & 1.103 & & & \\
\hline & $\begin{array}{l}\text { Direct } \\
\text { Customer }\end{array}$ & 4.03 & 0.915 & & & \\
\hline & Total & 3.92 & 0.967 & & & \\
\hline \multirow{4}{*}{$\begin{array}{l}\text { Human resource } \\
\text { management increases } \\
\text { sales }\end{array}$} & $\begin{array}{l}\text { Wholesaler/ } \\
\text { Dealer }\end{array}$ & 3.83 & 1.129 & \multirow{4}{*}{0.61} & \multirow{4}{*}{0.545} & \multirow{4}{*}{$\begin{array}{l}\text { Not } \\
\text { significant }\end{array}$} \\
\hline & Retailer & 3.64 & 1.342 & & & \\
\hline & $\begin{array}{l}\text { Direct } \\
\text { Customer }\end{array}$ & 3.9 & 1.011 & & & \\
\hline & Total & 3.82 & 1.13 & & & \\
\hline \multirow{4}{*}{$\begin{array}{l}\text { Products made in Nepal } \\
\text { doesn't decrease cost } \\
\text { of sales }\end{array}$} & $\begin{array}{l}\text { Wholesaler/ } \\
\text { Dealer }\end{array}$ & 2.88 & 1.329 & \multirow{4}{*}{0.797} & \multirow{4}{*}{0.453} & \multirow{4}{*}{$\begin{array}{l}\text { Not } \\
\text { significant }\end{array}$} \\
\hline & Retailer & 3.06 & 1.273 & & & \\
\hline & $\begin{array}{l}\text { Direct } \\
\text { Customer }\end{array}$ & 2.73 & 1.153 & & & \\
\hline & Total & 2.85 & 1.221 & & & \\
\hline $\begin{array}{l}\text { Solar related product } \\
\text { cannot be easily }\end{array}$ & $\begin{array}{l}\text { Wholesaler/ } \\
\text { Dealer }\end{array}$ & 2.54 & 1.103 & 0.164 & 0.849 & $\begin{array}{l}\text { Not } \\
\text { significant }\end{array}$ \\
\hline
\end{tabular}




\begin{tabular}{|c|c|c|c|c|c|c|}
\hline $\begin{array}{c}\text { Factors of value chain of } \\
\text { solar PV }\end{array}$ & $\begin{array}{c}\text { Target } \\
\text { Market }\end{array}$ & Mean & $\begin{array}{c}\text { Std. } \\
\text { Deviation }\end{array}$ & $\begin{array}{c}\text { F- } \\
\text { value }\end{array}$ & $\begin{array}{c}P \text { - } \\
\text { value }\end{array}$ & Remarks \\
\hline \multirow[t]{3}{*}{ imported } & Retailer & 2.64 & 1.113 & & & \\
\hline & $\begin{array}{l}\text { Direct } \\
\text { Customer }\end{array}$ & 2.68 & 0.947 & & & \\
\hline & Total & 2.64 & 1.019 & & & \\
\hline \multirow{4}{*}{$\begin{array}{l}\text { Marketing } \\
\text { increases profit }\end{array}$} & $\begin{array}{l}\text { Wholesaler/ } \\
\text { Dealer }\end{array}$ & 3.62 & 0.77 & \multirow{4}{*}{3.934} & \multirow{4}{*}{0.022} & \multirow{4}{*}{ Significant } \\
\hline & Retailer & 3.39 & 1.144 & & & \\
\hline & $\begin{array}{l}\text { Direct } \\
\text { Customer }\end{array}$ & 3.94 & 0.84 & & & \\
\hline & Total & 3.72 & 0.943 & & & \\
\hline
\end{tabular}

The above table shows the response of companies targeting different market towards factors of value chain. The companies targeting direct customer (4.03) strongly agree that infrastructure increases brand value of the company whereas companies targeting wholesaler/ dealer (3.82) and retailer (3.75) only agree that infrastructure increases brand value of the company. Since p value $(0.381)$ is greater than (0.05), null hypothesis is not rejected. Thus, there is no significant relationship between targeted market and infrastructure being the factor for increment in the brand value of the company. The companies targeting direct customer (3.9), wholesaler/ dealer (3.83) and retailer (3.64) agree that human resource management increases sales. Since p value $(0.545)$ is greater than $(0.05)$, null hypothesis is not rejected. Thus, there is no significant relationship between targeted market and human management increasing sales. The companies targeting retailer (3.06) is neutral whereas direct customer (2.73) and wholesaler/ dealer (2.88) disagree that made in Nepal products decrease cost of sales. Since p value $(0.453)$ is greater than (0.05), null hypothesis is not rejected. Thus, there is no significant relationship between targeted market and product manufactured in Nepal decreasing cost of sales.

The companies targeting direct customer (2.68), wholesaler/ dealer (2.54) and retailer (2.64) disagree that solar related products cannot be easily imported. Since $\mathrm{p}$ value (0.849) is greater than (0.05), null hypothesis is not rejected. Thus, there is no significant relationship between targeted market and solar related product being easily importable. The companies targeting direct customer (2.68), wholesaler/ dealer (2.54) and retailer (2.64) disagree that solar related product cannot be easily imported. Since $p$ value $(0.849)$ is greater than $(0.05)$, null hypothesis is not rejected. Thus, there is no significant relationship between targeted market and solar related product being easily importable. The companies targeting direct customer (3.94), retailer (3.39) and wholesaler/ dealer (3.62) agree on marketing increases profit. Since p value $(0.022)$ is less than $(0.05)$, null hypothesis is 
rejected. Thus, there is significant relationship between targeted market and marketing being factor for the increment of profit.

\subsection{Cross tabulation analysis}

Table 2: Analysis between import and target market

\begin{tabular}{|l|l|l|l|l|}
\hline \multirow{2}{*}{ Import } & \multicolumn{4}{|l|}{ Target market } \\
\cline { 2 - 5 } & Wholesaler/ Dealer & Retailer & Direct Customer & Total \\
\hline India & $54.20 \%$ & $27.30 \%$ & $15.90 \%$ & $26.70 \%$ \\
\hline China & $29.20 \%$ & $33.30 \%$ & $19.00 \%$ & $25.00 \%$ \\
\hline Japan & $0.00 \%$ & $3.00 \%$ & $4.80 \%$ & $3.30 \%$ \\
\hline Bangladesh & $4.20 \%$ & $0.00 \%$ & $1.60 \%$ & $1.70 \%$ \\
\hline Local market & $12.50 \%$ & $36.40 \%$ & $58.70 \%$ & $43.30 \%$ \\
\hline Total & $100.00 \%$ & $100.00 \%$ & $100.00 \%$ & $100.00 \%$ \\
\hline
\end{tabular}

The table shows the relationship between companies targeting different market and import of the solar PV home system. 54.20\% companies that have targeted wholesaler/ dealer import from India whereas $4.20 \%$ import from Bangladesh. $36.40 \%$ companies that have targeted retailer purchase from local market however $3 \%$ import from Japan. $58.70 \%$ companies that have targeted direct customer purchase highly from local market whereas $1.60 \%$ import from Bangladesh. Most of the companies prefer solar related product from local market. Since $\Sigma 2$ value is 23.268 with $p$ value 0.003 that is less than $0.05 \alpha$ value, null hypothesis is rejected. Thus, there is significant relationship between import and target market of solar PV industry.

Table 3: Analysis between subsidy claim and target market

\begin{tabular}{|l|l|l|l|l|}
\hline \multirow{2}{*}{ Subsidy claim } & \multicolumn{4}{|l|}{ Target market } \\
\cline { 2 - 5 } & Wholesaler/ Dealer & Retailer & Direct Customer & Total \\
\hline Yes & $87.50 \%$ & $72.70 \%$ & $47.60 \%$ & $62.50 \%$ \\
\hline No & $12.50 \%$ & $27.30 \%$ & $52.40 \%$ & $37.50 \%$ \\
\hline Total & $100.00 \%$ & $100.00 \%$ & $100.00 \%$ & $100.00 \%$ \\
\hline
\end{tabular}

The above table shows the relationship between subsidy claim and the target market. $87.50 \%$ of the companies that have targeted wholesaler/ dealer claim subsidy. $72.70 \%$ of the companies targeting retailer also claim subsidy provided by AEPC. However, only $47.60 \%$ of the companies that have targeted direct customer claim subsidy from AEPC. Most of the companies claim subsidy provided by AEPC. Since $\Sigma 2$ value is 13.825 with $p$ value 0.001 that is less than $0.05 \alpha$ value, null hypothesis is rejected. Thus, there is significant relationship between subsidy claim and target market of solar PV industry. 
Table 4: Analysis between marketing approach and target market

\begin{tabular}{|l|l|l|l|l|l|l|l|l|l|l|l|}
\hline \multirow{2}{*}{$\begin{array}{l}\text { Target } \\
\text { Market }\end{array}$} & \multicolumn{2}{|l|}{ Radio } & \multicolumn{2}{l}{ T.V. } & \multicolumn{2}{l|}{ Newspaper } & \multicolumn{2}{l|}{ Demonstration } & \multicolumn{2}{l|}{ Exhibition } \\
\cline { 2 - 10 } \\
$\begin{array}{l}\text { Wholesaler } \\
\text { Dealer }\end{array}$ & $37.50 \%$ & $62.50 \%$ & $66.70 \%$ & $33.30 \%$ & $45.80 \%$ & $54.20 \%$ & $33.30 \%$ & $66.70 \%$ & $83.30 \%$ & $16.70 \%$ \\
\hline Retailer & $33.30 \%$ & $66.70 \%$ & $69.70 \%$ & $30.30 \%$ & $60.60 \%$ & $39.40 \%$ & $39.40 \%$ & $60.60 \%$ & $78.80 \%$ & $21.20 \%$ \\
\hline $\begin{array}{l}\text { Direct } \\
\text { Customer }\end{array}$ & $63.50 \%$ & $36.50 \%$ & $76.20 \%$ & $23.80 \%$ & $38.10 \%$ & $61.90 \%$ & $23.80 \%$ & $76.20 \%$ & $55.60 \%$ & $44.40 \%$ \\
\hline Total & $50.00 \%$ & $50.00 \%$ & $72.50 \%$ & $27.50 \%$ & $45.80 \%$ & $54.20 \%$ & $30.00 \%$ & $70.00 \%$ & $67.50 \%$ & $32.50 \%$ \\
\hline
\end{tabular}

The table shows the relationship between marketing approach and target market. $66.70 \%$ of the companies that have targeted retailer use radio as marketing tools. Since $\Sigma 2$ value is 9.754 with $p$ value 0.008 that is less than $0.05 \alpha$ value, null hypothesis is rejected. Thus, there is significant relationship between uses of radio and target market of solar PV industry. 33.30\% of the companies that have targeted wholesaler/dealer use T.V as marketing tool. Since $\Sigma 2$ value is 0.970 with p value 0.616 that is greater than $0.05 \alpha$ value, null hypothesis is not rejected. Thus, there is no significant relationship between uses of T.V and target market of solar PV industry.

$61.90 \%$ of the companies that have targeted direct customer use Newspaper as marketing tool. Since $\Sigma 2$ value is 4.420 with p value 0.11 that is greater than $0.05 \alpha$ value, null hypothesis is not rejected. Thus, there is no significant relationship between uses of newspaper and target market of solar PV industry. $76.20 \%$ of the companies who have targeted direct customer demonstrate product while marketing. Since $\Sigma 2$ value is 2.663 with $p$ value 0.264 that is greater than $0.05 \alpha$ value, null hypothesis is not rejected. Thus, there is no significant relationship between demonstration of product and target market of solar PV industry. 83.30\% of the companies that have targeted wholesaler/ dealer do not consider exhibition as marketing tool. Since $\Sigma 2$ value is 8.757 with $p$ value 0.013 that is less than 0.05 $\alpha$ value, null hypothesis is rejected. Thus, there is significant relationship between exhibition of product and target market of solar PV industry.

Table 5: Analysis between distribution channel and target market

\begin{tabular}{|l|l|l|l|l|}
\hline \multirow{2}{*}{ Distribution channel } & \multicolumn{4}{|l|}{ Target market } \\
\cline { 2 - 5 } & Wholesaler/ Dealer & Retailer & Direct Customer & Total \\
\hline Import - Wholesaler & $100.00 \%$ & $0.00 \%$ & $0.00 \%$ & $20.00 \%$ \\
\hline Wholesaler - Retailer & $0.00 \%$ & $100.00 \%$ & $0.00 \%$ & $27.50 \%$ \\
\hline Retailer - Customer & $0.00 \%$ & $0.00 \%$ & $79.40 \%$ & $41.70 \%$ \\
\hline Importer - Customer & $0.00 \%$ & $0.00 \%$ & $15.90 \%$ & $8.30 \%$ \\
\hline Wholesaler - Customer & $0.00 \%$ & $0.00 \%$ & $4.80 \%$ & $2.50 \%$ \\
\hline Total & $100.00 \%$ & $100.00 \%$ & $100.00 \%$ & $100.00 \%$ \\
\hline
\end{tabular}


164 Rizal: Determinants of Value Chain Analysis of Solar Photovoltaic Industry in Kathmandu Valley

The above table shows the relationship between distribution channel and target market. $100 \%$ companies that have targeted wholesaler/ dealer follow importer wholesaler distribution channel, $100 \%$ companies that have targeted retailer follow wholesaler - retailer distribution channel, $100 \%$ companies that have targeted customer follow retailer- customer distribution channel, $100 \%$ companies that have targeted customer follows importer- customer distribution channel and 100\% companies that have targeted customer follow wholesaler- customer distribution channel. Most of the companies target direct customer instead wholesaler/ dealer or retailer. Since $\Sigma 2$ value is 2.400 with $\mathrm{p}$ value 0.00 that is less than $0.05 \alpha$ value, null hypothesis is rejected. Thus, there is significant relationship between distribution channel and target market of solar PV industry.

Table 6: Analysis between service and target market

\begin{tabular}{|l|l|l|l|l|l|l|l|l|l|l|}
\hline \multirow{2}{*}{$\begin{array}{l}\text { Target } \\
\text { Market }\end{array}$} & \multicolumn{2}{|l|}{ Warranty } & \multicolumn{2}{l}{ Installation } & \multicolumn{2}{l}{$\begin{array}{l}\text { Repair \& } \\
\text { Maintenance }\end{array}$} & \multicolumn{2}{l}{ Home Delivery } & \multicolumn{2}{l|}{ Exchange Offer } \\
\cline { 2 - 11 } & No & Yes & No & Yes & No & Yes & No & Yes & No & Yes \\
\hline $\begin{array}{l}\text { Wholesaler } \\
\text { Dealer }\end{array}$ & $8.30 \%$ & $91.70 \%$ & $41.70 \%$ & $58.30 \%$ & $20.80 \%$ & $79.20 \%$ & $58.30 \%$ & $41.70 \%$ & $79.20 \%$ & $20.80 \%$ \\
\hline Retailer & $18.20 \%$ & $81.80 \%$ & $36.40 \%$ & $63.60 \%$ & $24.20 \%$ & $75.80 \%$ & $39.40 \%$ & $60.60 \%$ & $81.80 \%$ & $18.20 \%$ \\
\hline $\begin{array}{l}\text { Direct } \\
\text { Customer }\end{array}$ & $27.00 \%$ & $73.00 \%$ & $52.40 \%$ & $47.60 \%$ & $23.80 \%$ & $76.20 \%$ & $28.60 \%$ & $71.40 \%$ & $55.60 \%$ & $44.40 \%$ \\
\hline Total & $20.80 \%$ & $79.20 \%$ & $45.80 \%$ & $54.20 \%$ & $23.30 \%$ & $76.70 \%$ & $37.50 \%$ & $62.50 \%$ & $67.50 \%$ & $32.50 \%$ \\
\hline
\end{tabular}

The table shows the relationship between service factors and target market. Most of the companies $(91.70 \%)$ provide warranty as after sales service. Since $\Sigma 2$ value is 3.859 with $\mathrm{p}$ value 0.145 that is greater than $0.05 \alpha$ value, null hypothesis is not rejected. Thus, there is no significant relationship between warranty and target market of solar PV industry. $63.60 \%$ of the companies who have targeted retailer provide installation as after sales service. Since $\Sigma 2$ value is 2.448 with p value 0.294 that is greater than $0.05 \alpha$ value, null hypothesis is not rejected. Thus, there is no significant relationship between installation and target market of solar PV industry.

$79.20 \%$ of the companies who have targeted wholesaler/dealer provide repair \& maintenance as after sales service. Since $\Sigma 2$ value is 0.107 with $p$ value 0.948 that is greater than $0.05 \alpha$ value, null hypothesis is not rejected. Thus, there is no significant relationship between consideration of repair \& maintenance and target market of solar PV industry. $71.40 \%$ of the companies who have targeted direct customer provide home delivery as after sales service. Since $\Sigma 2$ value is 6.638 with $\mathrm{p}$ value 0.036 that is less than $0.05 \alpha$ value, null hypothesis is rejected. Thus, there is significant relationship between home delivery and target market of solar PV 
industry. $81.80 \%$ of the companies who have targeted retailer do not provide exchange offer as after sales service. Since $\Sigma 2$ value is 8.670 with p value 0.013 that is less than $0.05 \alpha$ value, null hypothesis is rejected. Thus, there is significant relationship between exchange offer and target market of solar PV industry.

Table 7: Analysis between cost of sales reducing ways and target market

\begin{tabular}{|l|c|c|c|c|c|c|c|c|c|c|}
\hline \multirow{2}{*}{$\begin{array}{c}\text { Target } \\
\text { Market }\end{array}$} & \multicolumn{2}{|c|}{ Made in Nepal } & \multicolumn{2}{c|}{$\begin{array}{c}\text { Battery } \\
\text { recycling } \\
\text { plant }\end{array}$} & \multicolumn{2}{c|}{$\begin{array}{c}\text { Same capacity of } \\
\text { battery and panel }\end{array}$} & \multicolumn{2}{c|}{$\begin{array}{c}\text { Volume } \\
\text { purchase }\end{array}$} & \multicolumn{2}{c|}{$\begin{array}{c}\text { Sale of } \\
\text { LED bulb }\end{array}$} \\
\cline { 2 - 11 } & No & Yes & No & Yes & No & Yes & No & Yes & No & Yes \\
\hline $\begin{array}{l}\text { Wholesaler } \\
\text { / Dealer }\end{array}$ & $50.00 \%$ & $50.00 \%$ & $58.30 \%$ & $41.70 \%$ & $70.80 \%$ & $29.20 \%$ & $62.50 \%$ & $37.50 \%$ & $62.50 \%$ & $37.50 \%$ \\
\hline Retailer & $60.60 \%$ & $39.40 \%$ & $60.60 \%$ & $39.40 \%$ & $78.80 \%$ & $21.20 \%$ & $60.60 \%$ & $39.40 \%$ & $60.60 \%$ & $39.40 \%$ \\
\hline $\begin{array}{l}\text { Direct } \\
\text { Customer }\end{array}$ & $73.00 \%$ & $27.00 \%$ & $85.70 \%$ & $14.30 \%$ & $76.20 \%$ & $23.80 \%$ & $31.70 \%$ & $68.30 \%$ & $31.70 \%$ & $68.30 \%$ \\
\hline Total & $65.00 \%$ & $35.00 \%$ & $73.30 \%$ & $26.70 \%$ & $75.80 \%$ & $24.20 \%$ & $45.80 \%$ & $54.20 \%$ & $45.80 \%$ & $54.20 \%$ \\
\hline
\end{tabular}

The above table shows the relationship between cost of sales reducing ways and target market. $73 \%$ of the companies that have targeted direct customer do not consider Nepal manufactured product decreasing cost of sales. Most of the companies consider Nepal manufactured product not decreasing cost of sales. Since $\Sigma 2$ value is 4.433 with $\mathrm{p}$ value 0.109 that is greater than $0.05 \alpha$ value, null hypothesis is not rejected. Thus, there is no significant relationship between made in Nepal product and target market of solar PV industry. $85.70 \%$ of the companies that have targeted direct customer do not consider battery recycling plant decreasing cost of sales. Most of the companies consider battery recycling plant not decreasing cost of sales. Since $\Sigma 2$ value is 10.433 with p value 0.005 that is greater than $0.05 \alpha$ value, null hypothesis is rejected. Thus, there is significant relationship between battery recycling plant and target market of solar PV industry.

$78.70 \%$ of the companies that have targeted retailer do not consider same capacity of panel and battery decreasing cost of sales. Most of the companies consider same capacity of panel and battery not decreasing cost of sales. Since $\Sigma 2$ value is 0.489 with $\mathrm{p}$ value 0.783 that is greater than $0.05 \alpha$ value, null hypothesis is not rejected. Thus, there is no significant relationship between capacity of panel and battery and target market of solar PV industry. $68.30 \%$ of the companies who have targeted direct customer consider volume purchase decreases cost of sales. Most of the companies consider volume purchase decreases cost of sales. Since $\Sigma 2$ value is 10.622 with $p$ value 0.005 that is less than $0.05 \alpha$ value, null hypothesis is rejected. Thus, there is significant relationship between volume purchase and target market of solar PV industry. $68.30 \%$ of the companies who have targeted direct customer consider sale of LED bulb decreases cost of sales. Most of the companies consider 
sale of LED bulb decreases cost of sales. Since $\Sigma 2$ value is 10.622 with p value 0.005 that is less than $0.05 \alpha$ value, null hypothesis is rejected. Thus, there is significant relationship between sale of LED bulb and target market of solar PV industry.

\section{Concluding Remarks}

The study shows that factors influencing value chain of solar PV industry are infrastructure (mostly furniture, workshop, showroom, capital and human resources in less number) needed to set up a company, import from different countries, distribution channel, subsidy claim, marketing medium and after sales service. These companies have nearly 16 to 25 employees currently working under them.

Most of the companies consider furniture, workshop, showroom and capital as an important infrastructure to set up a company. Very few companies import huge quantity of the system whereas most of the companies purchase the systems from them. Most of the companies targeting retailer consider radio and the companies targeting direct customers consider newspaper, demonstration as marketing medium whereas companies targeting retailer don't consider T.V and the companies targeting wholesalers/ dealers don't consider exhibition as marketing medium. Most of the respondent companies targeting wholesaler/ dealer provide warranty, and repair \& maintenance whereas most companies targeting retailer provide installation and exchange offer as after sales service and the companies targeting direct customers provide home delivery as after sales service. Most of the companies targeting direct customers don't claim subsidy directly. They either don't claim at all or they claim via other pre-qualified companies. Most of the companies targeting direct customer follow retailer- customer, importer- customer and wholesaler- customer. Most of the companies targeting direct customer don't consider made in Nepal, battery recycling plant and the companies targeting retailer don't consider equal capacity of panel and battery whereas companies targeting direct customer consider volume purchase and sale of LED bulb as after sales service. The different target markets consider the factors of value chain of solar PV to be important part in creating value in every process starting from import. Along more number of human resources contribute in creating efficient servicing with more training and skills.

Although various aspects of the value chain have been considered, this study has not included profit margin as one of the study since the respondents are not willing to answer the typical questions related to profit. Apart from that, this study is based only on Kathmandu Valley which represents a small portion of the country. This study has 
formed the base for the further study that can be conducted on the topic related to marketing or finance or human resource in the field of solar PV home system.

It is suggested to make solar related product free from custom duty and other charges so as to make it more inexpensive and easily accessible in the market via governmental policies. Panels as well as parts such as deep-cycle batteries, cables, controllers, inverters, and chargers should be zero-rated for duties. From this study, government can influence financial institutions to help provide financial support to potential customers seeking to buy the solar products. This will certainly help customers during load shedding hours.

\section{References}

Achchuthan, S., \& Kajananthan, R. (2012). A study on value chain analysis in dairy sector Kilinochchi district, Sri Lanka. Global Journal of Management and Business Research, Vol. 12(21), 1-14.

Alternative Energy Promotion Centre (2015). Yearwise installation of solar systems. Ministry of Population and Environment, Nepal.

Hergert, M. \& Morris, D (1989). Accounting data for value chain analysis. Strategic Management Journal, Vol. 10(2), 175-188.

Du Toit, H.J. (2010). Investigating Opportunities for Local Economic Developemnt, Poverty Allevation and Energy Consumption, A MPhil Degree's Thesis Submitted to Stellenbosch University.

Institute for Labor Studies. (2009). Value chain analysis of solar water heater industry: A Case Study in the City of Dezhon.

Ireland, D.R., Hitt, M.A. \& Sirmon D.G. (2009). A model of strategic entrepreneurship: The construct and its dimensions. Journal of Management, Vol. 29(6), 40-53.

Xiang, H., Saeedi, M., Shen, Z. \& Sundaresan, N. (2013). From lemon markets to managed markets: The evolution of ebay's reputation system. Working Paper, Ohio State University.

Malik, S., Mayer, J. \& Aguilar, L.A. (2016). Value chain analysis of the solar PV market in Pakistan. Internationale Zusammenarbeit (GIZ) GmbH, Deutsche Gesellschaft für, Germaney.

Mowen, M.M. \& Hansen, D.R. (2013) Introduction to cost accounting. SouthWestern Cengage Learning, Philippine edition, Singapore: Cengage Learning Asia Pvt. Ltd. 
168 Rizal: Determinants of Value Chain Analysis of Solar Photovoltaic Industry in Kathmandu Valley

Olson, E. L. (2014). Green innovation value chain (GIVC) analysis of PV solar power. Journal of Cleaner Production, Vol. 64, 73-80.

Porter, M. (1985). The Competitive Advantage: Creating and Sustaining Superior Performance. New York: Free Press.

Roberts, J. W. (2011). Can Warranties substitute for reputations? American Economic Journal: Microeconomics, Vol. 3(3), 69-85.

Winter, G. S., McIntosh, J., \& May, D. (2003). Survival in the Korean furniture industry. Journal of Managerial Issues, Vol. 15(4), 450-466.

Xiao, Mo. (2010). Is quality certification effective? Evidence from the childcare market. International Journal of Industrial Organization, 28(6), 708-721. 